\title{
Marriage Services at The Office of Religious in The Pandemic Era of Covid-19
}

\author{
Heesam Dorni $^{1}$, Endang Larasati ${ }^{2}$, Teuku Afrizal ${ }^{3}$, Retno Sunu Astuti ${ }^{4}$ \\ Student of Master of Public Administration, FISIP, Diponegoro University ${ }^{1}$ \\ Lecturers of the Master of Public Administration Study Program, FISIP, Diponegoro University $2,3,4$ \\ Email: heesam170937@gmail.com
}

(Received: May 15-2020; revised: Juny 10-2020; published: December 31-2020)

\begin{abstract}
The Covid-19 pandemic has caused major changes in almost all aspects of human life, including the implementation of public services. Government policies that implement work from home (WFH) for government agencies located in areas with a certain risk of transmission, have caused public service activities to undergo changes. public services during the Covid-19 pandemic while maintaining health protocols has become a separate issue and has led to many innovations in the field of public services. One of the public services affected during the Covid-19 pandemic is marriage services at the Office of Religious Affairs (KUA). Complaints from a number of communitiesaimed at marriage services at the KUA with suspected maladministration. This study aims to analyze marriage services at the KUA during the Covid-19 pandemic. The study was conducted using the literature study method with data sources for journal articles, government agency websites and related documents. Since the beginning of the pandemic period, the implementation of marriage services at the KUA has been regulated by three circular letters from the Director General of Islamic Community Guidance at the Ministry of Religion, taking into account developments in the condition of the community. Online marriage registration is optimized, and is demonstrated by the high rate of registration of marriage registrations during the Covid-19 pandemic.
\end{abstract}

Keywords: marriage services, online service, pandemic era

\section{INTRODUCTION}

The Covid-19 pandemic has become a major problem for the world since its first appearance in Wuhan, China in December 2019. Covid-19 stands for CoronaVirus Disease2019 , which is an infectious disease caused by a newly discovered type of coronavirus. The Covid-19 pandemic is not only threatens human health, but has also negatively affected the world economy (Shangguan, Wang, \& Sun, 2020). The large-scale limitation of human activities in an effort to stop the spread of the virus reduces various economic activities and causes various health, social and economic problems that can change rapidly, are unpredictable, uncertain, complex and can cause turmoil in society (Amalia, 2020). Global conditions indicate there are $216 \mathrm{n}$ egara infected, with unconfirmed numbers 17660.523 inhabitants and the death rate 680894 inhabitants (WHO data as of August 2, 2020 in covid19.go.id). In Indonesia alone, the confirmed figure reached 353,461 people, the cure rate was 277,544 people and the death rate was 12,347 people (covid19.go.id, data on 16 October 2020).

The government is the main actor who has to adjust to be able to solve the various problems caused by the spread of Covid-19. The Indonesian government issued Government 
308 | Jurnal Ilmiah Ilmu Administrasi Publik: Jurnal Pemikiran dan Penelitian Administrasi

Volume 10 Number 2, July-December 2020. Page 307-318

Regulation (PP) Number 21 of 2020 concerning Large-Scale Social Restrictions in the Context of Accelerating the Handling of Corona Virus Disease 2019 (Covid-19) which was signed on March 31, 2020. In this regulation, what is meant by Large-Scale Social Restrictions (PSBB)) is a restriction on certain activities of residents in an area suspected of being infected with Covid19 in such a way as to prevent the possibility of the spread of Covid-19. PSBB includes school and work vacations; restrictions on religious activities; restrictions on activities in public places or facilities. With the social restriction policy set by the government, of course it will have an impact on almost all aspects of public life, including the public service sector. The impact on the public service sector is also influenced by the Circular of the Minister of Administrative Reform and Bureaucratic Reform Number 67 of 2020 concerning Amendments to the Circular of the Minister of Administrative Reform and Bureaucratic Reform Number 58 of 2020 concerning the Work System of State Civil Servants in the New Normal Order, which stipulates that government employees in districts / cities with a certain level of risk can carry out their official duties at home (work from home or WFH). This situation certainly affects the service quality of government offices which is not optimal.

One of the public services affected by the Covid-19 pandemic is the marriage service at the Religious Affairs Office. Services at the Religious Affairs Office (KUA) as an arm of the Ministry of Religious Affairs in the pandemic Covid-19 complained of a number of people with alleged maladministration by with holding the protracted process of service, demand in exchange for money, goods and services (extortion) to the provision of the service is not worth (https://ombudsman.go.id/artikel/r/artikel--menyoroti-pelayanan-kua-di-masa-pandemi).

Referring to KEP/25/M.PAN/2/2014, the definition of marriage service is all service activities carried out by the Office of Religious Affairs starting from pre-marriage, implementation and post-marriage as an effort to meet community needs. Marriage services are closely related to the duties and functions of the Office of Religious Affairs (KUA), the task of the KUA is to carry out some of the duties of the District and City Department of Religion Offices in the field of Islamic Religious Affairs in the District (KMA No.517 of 2001). Thus, the KUA carries out two functions: organizing statistics and documentation, organizing correspondence, archiving, typing, and household KUA Kecamatan; and carry out marriage registration, reconciliation, manage and foster mosques, zakat, waqf, baitul maal and social worship, population and family development of the sakinah family in accordance with the policies set by the Director General of Islamic Community Guidance based on the prevailing laws and regulations (KMA No. 517 of 2001). Since the reformation began, the community's bargaining power has grown stronger in terms of public services. The Ministry of Religion has agreed that public services are the most visible measure of government performance, for example, improving marriage services at the KUA (https://simlitbangdiklat.kemenag.go.id/simlitbang /spdata / upload / dokumen-pen Research / 1489461852L Report_Hasil_Pen_Research_Tim_Kehidup_tentuk_2.pdf).

People always demand quality public services from bureaucrats. Public services have very broad implications because they touch all public spaces in economic, social, political, cultural and other life. In state life, the government has the function of providing various public services 
needed by the community, ranging from services in the form of regulations or other services in order to meet community needs in the fields of education, health, utilities and others (Mohammad in Mahsyar, 2011). Poor public services in a country can cause effects in many aspects of life. For example, in the economic sector, it will have implications for a decrease in investment; in political life will have implications for public trust in the government; from social aspects of culture resulted in disruption of community psychology, as indicated by reduced sense of mutual respect among communities (Mahsyar, 2011).

Taufik Research (2020) concluded that Covid-19 condition requires the civil servant to generate creativity and innovation in the service of the online-based public services. Berbagai more massive publik. Namun implemented in service delivery, there are still some obstacles in which the bureaucracy is still less responsive in the delivery service to the community so that it is necessary to improve the quality of public services so that the level of public satisfaction with government services is higher even in the conditions of the Covid-19 pandemic. Another thing that is no less important is that the health and safety of civil servant and the public are the main priorities that must be considered in the Covid-19 condition. Therefore, the implementation of public services throughout Indonesia must be in accordance with health protocols, so that the covid-19 spread chain ends soon and public services continue to run back to normal.

Government officials are required to maintain the continuity of services by changing the way of services that limit the physical distance between the government and citizens as service users (physical distancing). Changing the way of service to community members is an undeniable necessity. This is in line with the principles of continuity and adaptability in public services. Continuity means that public services to community members must not be stopped during a pandemic, basic services are still provided, at least through the provision of minimum services. Meanwhile, adaptive is understood as an adjustment to the way of service during the epidemic which provides easy access to public services for citizens (https://ombudsman.go.id/artikel/r/artikel-- Evaluation-pelayanan-publik-selama-pandemi). By seeing the importance of the quality of public services that must be optimal in various conditions, this study aims to analyze the marriage services at the KUA during the Covid-19 pandemic.

\section{METHOD}

This study used a qualitative descriptive approach through library (library research) by utilizing the appropriate journals with research topics, websites of government agencies and other important documents related. The focus of research in this paper is on marriage services in the KUA during the Covid-19 pandemic. The data collection technique in this research is through documentation. The analysis method used in this research is interactive analysis with three components of analysis, namely data reduction, data presentation and drawing conclusions (Sugiyono, 2011). 
Volume 10 Number 2, July-December 2020. Page 307-318

\section{RESULT AND DISCUSSION}

The Indonesian government through the Head of the National Disaster Management Agency determined the Corona Virus or Covid-19 outbreak as a National Disaster on March 14, 2020 (http://sehatnegeriku.kemkes.go.id/baca/rilis-media/20200315/3633379/status-wabahCorona-Indonesia-declared-disaster-national/) In connection with this, a number of public services have been affected, one of which is the marriage service at the KUA. The Ministry of Religion announced the closure of marriage services in early April 2020, so that the public is urged to postpone or reschedule plans for the implementation of marriage during the Covid-19 emergency. The implementation of the marriage contract service is only for brides who register before April 1, 2020, and will only be carried out at the KUA, not outside the KUA. However, registration of marriage registration services is still open and carried out online via the simkah.kemenag.go.id page (https://diy.kemenag.go.id/5902-akad-nikah-di-tengah-covid-19ribuan- bride and groom-to-be-married-before-april.html). These provisions are listed in the Circular of the Director General of Islamic Community Guidance Number: P-02/DJ.III/ Hk.00.7/03/2020 concerning Appeals and Implementation of the Protocol for Handling COVID19 in Public Areas in the Dirjen Bimas Islam on point 3 regarding prevention protocols. The spread of Covid-19 on Marriage Services at KUA, namely as follows:

1. Spread of Covid-19 at the Akad Marriage service at KUA.

a. Limiting the number of people participating in the marriage ceremony procession in one room to no more than 10 people;

b. Catin and family members who follow the procession must have washed their hands with soap / hand sanitizer and used a mask; and

c. Officers, Marriage Guardians and Male Catin wearing gloves and masks during the consent of the marriage;

2. Temporarily eliminating all types of services other than administration and registration services at KUA, which have the potential to establish close contact and create crowds such as: marriage guidance for catin, marriage consultation, classical guidance and so on; and

3. Always coordinate with health workers in the context of preventing the spread of Covid-19, including providing the necessary referrals when there are signs and symptoms of illness, both to officers and the community during service.

The service for the marriage contract at the District Office of Religious Affairs (KUA) was reopened on April 23, 2020 based on the provisions in the Circular of the Director General of Islamic Community Guidance of the Ministry of Religion No. Disaster Emergency Period due to Covid-19 Disease Outbreak. Some of the provisions in letter E listed in the circular letter are as follows:

1. The implementation of the marriage contract is held at the District Office of Religious Affairs (KUA). 
2. The implementation of the marriage contract is only permitted for brides who have registered until April 23, 2020.

3. Applications for marriage contracts registered after 23 April 2020 cannot be implemented until 29 May 2020.

4. The District KUA is obliged to regulate matters relating to the officer, the prospective bride and groom, the time and place so that the implementation of the marriage contract and health protocol can run as well as possible.

5. To avoid crowds in the sub-districts KUA, the implementation of the marriage contract in the office is limited to a maximum of eight pairs of prospective brides in one day.

Implementation of the marriage contract based on these provisions is only intended for brides who have registered until April 23, 2020, while applications for marriage contracts registered after April 23, 2020 cannot be carried out until May 29, 2020 (https://setkab.go.id/layanan- akad-nikah-di-kua-re-opened-for-registrants-until-23-april-2020/). The implementation of the marriage contract at the KUA continues to apply health protocols in the prevention of Covid-19. If this cannot be fulfilled, the District KUA must refuse service. The Sub-district KUA is also required to coordinate and cooperate with related parties and security forces to control the implementation of the marriage contract service. Petition filed after the marriage ceremony fulfilled the quota per day (maximum of eight pairs of bride), The District KUA can suspend the implementation of the marriage contract in another place. If for some reason or urgent situation, the bride and groom are unable to carry out the marriage at the KUA, then head of KUA If the bride and groom register after April 23, but there is an urgent reason for the marriage contract to be hastened, the head of the KUA can also consider the application for the implementation of the contract, when the service quota is eight pairs of prospective brides per the day is full, if there is an acceptable compelling reason.

The Ministry of Religion, through the Directorate General of Islamic Community Guidance, issued the latest policy regarding marriage services in Circular Number P006/DJ.III/Hk.00.7/06/2020 concerning Guidelines for Implementation of Marriage Services during the Covid-19 Pandemic which was published on June 10, 2020 and stated that that the public is allowed to carry out the marriage contract outside the KUA. However, there are conditions that must be met by the prospective bride if she wants to enter into a marriage contract outside the KUA. With the publication of this circular, the prospective bride and groom are allowed to enter into a marriage contract at the KUA, house, mosque, or meeting hall. Ceremony at the KUA only can be attended by a maximum of 10 people, and the ceremony at the mosque or convention center, can be attended by a maximum of 30 people. The issuance of this circular is to provide a sense of security while still supporting the implementation of marriage services with a new normal order (new normal). This Circular of the Director General includes guidelines and provisions for the implementation of marriage services during the Covid-19 pandemic while still guided by Regulation of the Minister of Religion Number 20 2019 concerning the Registration of Marriage. The provisions in this Circular Letter include:

1. Marriage registration services at the District Office of Religious Affairs (KUA) are carried out every working day with a schedule following the stipulated work system provisions; 


\section{2 || Jurnal Ilmiah Ilmu Administrasi Publik: Jurnal Pemikiran dan Penelitian Administrasi Publik \\ Volume 1o Number 2, July-December 2020. Page 307-318}

2. Marriage registration can be done online, including through the simkah.kemenag.go.id website, telephone, e-mail or directly to the sub-districts KUA;

3. The provisions referred to in number 1 and number 2 and / or related to the process of marriage registration, marriage examination and implementation of the marriage contract are carried out with due observance of health protocols and as much as possible to reduce physical contact with District KUA officers;

4. The implementation of the marriage contract can be held at the KUA or outside the KUA;

5. Participants in the procession of the marriage contract held at the KUA or at home are followed by a maximum of 10 (ten) people;

6. Participants in the marriage ceremony procession carried out in the mosque or meeting hall are attended by a maximum of $20 \%$ of the room capacity and no more than 30 (thirty) people;

7. The District KUA is obliged to regulate matters relating to officers, Catin parties, time and place so that the implementation of the marriage contract and health protocol can run as well as possible;

8. In the case of the implementation of the marriage contract outside the KUA, the Head of the District KUA can coordinate and cooperate with related parties and / or security forces to control the implementation of the marriage contract service carried out in accordance with strict health protocols;

9. In the event that the health protocol and / or the provisions in number 5 and point 6 cannot be fulfilled, the Penghulu is obliged to refuse marriage services along with reasons for refusal in writing which are known to the security apparatus as shown in the attached form;

10. The Head of the District KUA shall coordinate on the plan to implement the new normal order of marriage services to the Head of the District Task Force; and

11. The Head of the Regency / City Ministry of Religious Affairs Office monitors and controls the implementation of the new normal order of marriage services in their respective areas. 


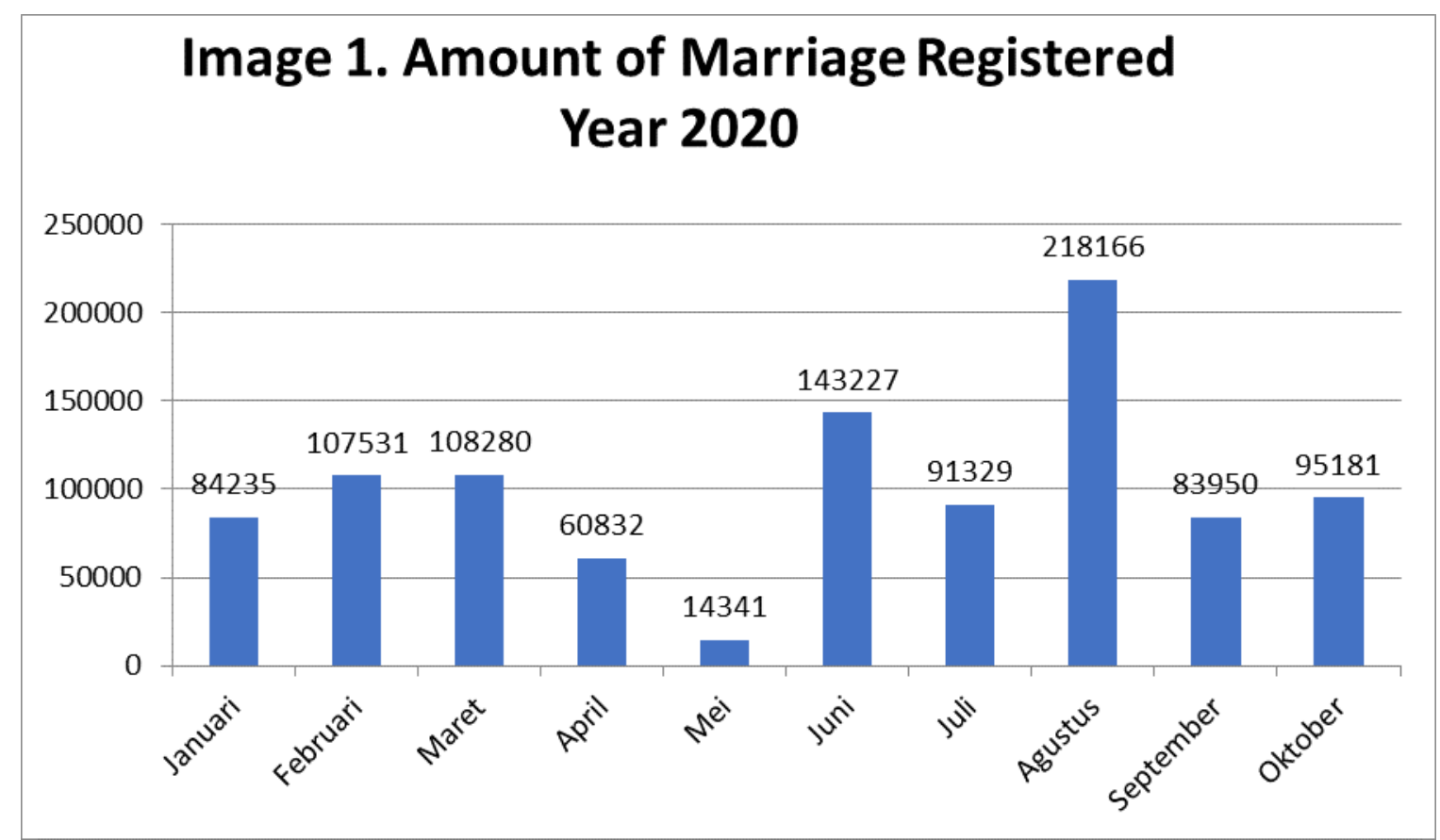

Source: http://simkah.kemenag.go.id/peristiwa, accessed October 22, 2020

The data obtained from simkah.kemenag.go.id in Figure 1 shows that only in April and May 2020, the number of marriage records tends to decline because there are service restrictions on the implementation of the marriage contract. However, marriage registration can still be done through the simkah page kemenag.go.id. Ministry of Religious Affairs noted the addition of tens of thousands of brides (catin) have signed kanper marriage late in online through the Management Information System of Marriage (SIMKAH) on the official website simkah.kemenag.go.id although $\mathrm{p}$ un MORA stop service at the beginning of the ceremony to the pandemic Covid-19 (https://www.cnnindonesia.com/nasional/20200413100623-20492931/30-ribu-pasangan-daftar-nikah-di-tengah-pandemi-corona).

The SIMKAH (Marriage Management Information System) Web application was launched by the Ministry of Religion of the Republic of Indonesia on November 8, 2018 and is a followup to the memorandum of understanding between the Minister of Religion and the Minister of Home Affairs Number: 470/5711/SJ and Number 20 of 2015 concerning Collaborative Utilization of Population Identification Numbers, Data Population and Electronic KTP within the scope of the Ministry of Religion. This application is easy to use (user friendly) so that it makes it easier for KUA officers to carry out their duties. This application is also easy to understand so it does not require continuous Technical Guidance (Bimtek). In essence, this application will facilitate services for the community and modernization in presenting data. SIMKAH has a number of advantages, namely First, this application is integrated with data at the relevant ministries nationally. For example, the Population Administration Information System (SIAK) from the Ministry of Home Affairs, the Online PNBP Information System 


\author{
314 Jurnal Ilmiah Ilmu Administrasi Publik: Jurnal Pemikiran dan Penelitian Administrasi \\ Publik \\ Volume 1o Number 2, July-December 2020. Page 307-318
}

(SIMPONI) from the Ministry of Finance, and the Case Tracking Information System (SIPP) from the Supreme Court. Second, when printing the marriage book, a QR code will appear that is connected to the application. This is a security feature to keep the marriage book from being easily faked by irresponsible parties. Third, the marriage data report and the marriage-referral PNBP can be seen in real-time. This will facilitate monitoring of the implementation of marriage nationally, including being able to monitor the availability of a marriage book in each region. Fourth, marriage registration can be done online. Prospective brides (catin) can fill in the initial data and book the desired wedding schedule. However, catin still has to submit physical documents to KUA officers. Fifth, this application also presents more data variables with certain categories, for example data on marriage based on age, education, occupation, and others. Sixth, the KUA is connected in realtime. When the public submits a marriage recommendation letter and the legalization of the marriage book, a notification will appear. With the existence of such innovative policies and services, the provision of public services to the public can continue amid fears of the spread of the Covid-19 outbreak. The community or the prospective bride and groom only need to follow the established procedure, the intention of building a household can also be realized. SIMKAH can be the best solution for the efforts of social order in the community, especially for couples who want to get married at the time of the Covid-19 era. SIMKAH is evidence of the growing spirit of Indonesia Serving that adapts to existing situations and conditions. It also confirms that public services remain held up by utilizing technology-based or online are increasing. In remain underserved communities with good, efforts to prevent the spread of the Covid-19 outbreak can be implemented according to the rules of health protocol (https://revolusimental.go.id/kabar/simkah-between-solutions-and-holyintention-marriage).

Optimizing the use of SIMKAH for marriage registration services during the Covid-19 pandemic shows that there is an increase in the use of information technology in public services in Indonesia at a time when the government requires implementing health protocols in every aspect of people's lives today. The presence of this electronic service is a form of innovation produced by the government during the Covid-19 pandemic, where public service delivery is carried out through an online system (Taufik, 2020). The Government that have increased their reliance padainternetdan digital devices during the crisis will maintain digitizing deeper levels tinggisetelah pandemic subsided (Brannen, 2020). Covid-19 has proven digital connectivity as an important means in the midst of a situation of lockdown and social restrictions (Brannen, 2020). Online-based services have greatly helped the government's performance in providing the best public services during the Covid-19 pandemic, one of which is SIMKAH. This of course can be an evaluation for the Ministry of Religion to maximize SIMKAH in marriage registration services, so that in the future the Ministry of Religion can become one of the modern agencies with the application of information technology in all lines of work.

Experience during the Covid-19 pandemic has made the central and local governments to innovate in order to continue to provide the best service to the public. Innovation in the public sector is a necessity in line with the government's desire to realize quality public services, despite the Covid-19 pandemic. Carried out with the hope that community needs, especially 
health service needs, basic needs, security needs, and other needs can still be fulfilled by the community. In the Covid-19 pandemic situation, the importance of innovation in public service delivery. Public service innovation can be in the form of services provided online and offline services. This is because Indonesia's geographical conditions are not uniform in the availability of infrastructure that supports online services. There are still areas or regions in Indonesia that still have difficulty accessing the internet. These areas can be served through offline services, but still prioritizing health protocols.

The government bureaucracy that is rigid and hierarchical should be transformed into agile public organizations and policies in order to be able to solve various public problems that arise during the Covid-19 pandemic. Public organizations realize that to be able to produce better public policies and services can be realized using an agile approach, namely working more strategically, flexibly and adaptively to change. Therefore, the agile approach is not a goal, but a means and conditions that encourage the government to work more effectively and / or efficiently (Purwanto, 2019). An agile approach to the organization can be achieved through the integration of the organization with the ability of human resources who are competent using technology. Therefore, organizations must encourage their human resources to master digital capabilities such as artificial intelligence, machine learning and predictive algorithms. The use of technology helps organizations understand the behavior and expectations of their service users properly so that they are able to make decisions and provide services according to the needs of service users (Purwanto, 2019).

\section{CONCLUSION}

A number of public services were affected when the Indonesian Government declared the Corona Virus or Covid-19 outbreak a National Disaster, one of which was the marriage service at the KUA. The Ministry of Religion announced the closure of marriage services in early April 2020, and reopened marriage services on April 23, 2020. The implementation of the marriage contract at the KUA continues to apply health protocols in preventing Covid-19. The Ministry of Religion issued a new circular in June 2020 and stated that the public is allowed to carry out the marriage contract outside the KUA. However, there are conditions that must be fulfilled by the prospective bride and groom if they want to enter into a marriage contract outside the KUA. With the publication of this circular, the prospective bride and groom are allowed to enter into a marriage contract at the KUA, house, mosque or meeting hall. Although the wedding service at KUA was closed for some time, but the Ministry of Religious Affairs noted the addition of tens of thousands of brides has registered marriage in online through the Management Information System of Marriage (SIMKAH). Optimizing the use of SIMKAH for marriage registration services during the Covid-19 pandemic shows that there is an increase in the use of information technology in public services in Indonesia at a time when the government requires implementing health protocols in every aspect of people's lives today. 


\section{REFERENCES}

Amalia, S. (2020). Through a pandemic with agile public organizations and policies. Journal of Performance Discourse , 2018-2020.

Arsyad, M. (2020). The Black Mantra of Public Service Processes: Questioning the State's Existence during the Covid-19 Pandemic. National Proceedings of Covid-19, 8996. Retrieved from https://ojs.literacyinstitute.org/index.php/prosidingcovid19/article/view/44

Brannen, S., Ahmed, H., \& Newton, H. (2020). Covid-19 Reshapes the Future. Center for Strategic and International Studies , 1-24.

Cimmino, J., Kroenig, M., Pavel, B., Cimmino, J., Kroenig, M., \& Pavel, B. (2020). Taking Stock: Where Are Geopolitics Headed in the. Atlantic Council Strategy Papers, (June), 0 21. Retrieved from http://www.jstor.com/stable/resrep24633

Covid-, MP, Darmawan, E., \& Atmojo, ME (2020). Work from Home Policy for State Civil Servants at . 1 (September), 92-99.

Deslatte, A. (2020). The Erosion of Trust During a Global Pandemic and How Public Administrators Should Counter It. American Review of Public Administration , 50 (6-7), 489-496. https://doi.org/10.1177/0275074020941676

Doramia Lumbanraja, A. (2020). The Urgency of Public Service Transformation through EGovernment on New Normal and Bureaucratic Regulatory Reform. Administrative Law and Governance Journal , 3 (2), 220-231. https://doi.org/10.14710/alj.v3i2.220-231

Hadi, K. (2016). Public Service Bureaucratic Corruption in the Era of Regional Autonomy. Political Research Journal,7(1), 20. Retrieved from http://ejournal.lipi.go.id/index.php/jppol/article/download/512/320

Kariem, MQ (2020). Conceptions of Government Policy in the New Normal Era. TheJournalish: Social and Government , 1, 76-80.

Khaleghi, A., Mohammadi, MR, Jahromi, GP, \& Zarafshan, H. (2020). New ways to manage pandemics: Using technologies in the era of COVID-19, a narrative review. Iranian Journal of Psychiatry , 15 (3), 236-242. https://doi.org/10.18502/ijps.v15i3.3816

Complete, T. (2020). MARETE: How public service workplace has evolved during Covid era. (June), 1-2.

Mahsyar, A. (2011). Public Service Problems in Indonesia in a Public Administration Perspective. Authority: Journal of Governmental Science, 1 (2), 8190. https://doi.org/10.26618/ojip.v1i2.22

Marwiyah, S., Halima, N., \& Maulidi, F. (2020). Analysis of Paternalistic Leadership Types in Improving Public Services in the Middle of the Covid-19 Pandemic Situation. Journal of $\begin{array}{llll}\text { Social and Political } & \text { Science }\end{array}$ https://doi.org/10.33474/jisop.v2i2.6689

Miyono, N. (nd). The Influence of Work Culture on The Quality of Marriage Service in Banyumas District The Influence of Work Culture on the Quality of Marriage Services in Banyumas Regency . 785-814. 
Nikah, M., Di, S., \& Kecamatan, KUA (nd). The effectiveness of the application of the marriage management information system (Simkah) in the Jatinangor sub-district, Sumedang district .

Rosidin, R. (2017). Index of the quality of marriage services in Central Java. IJTIHAD Discourse Journal of Islamic Law and Humanity, 16 (2), 257. https://doi.org/10.18326/ijtihad.v16i2.257-280

Schmitt, M. (2020). Report Part Title: In the Wake of Its COVID-19 Failure, How Do We Restore Trust in Government . New Americ a. https://www.jstor.org/stable/resrep25415.8

Shangguan, Z., Wang, MY, \& Sun, W. ( 2020 ). What Caused the Outbreak of COVID-19 in China: From the Perspective of Crisis Management. International Journal of Environmental Research and Public Health, 17, 116. https://doi.org/10.3390/ijerph17093279

Taufik, HW (2020). New Bureaucracy for New Normal: A Review of Bureaucratic Change Models in Public Services in the Covid-19 Era. Dialogue of Public Administration Science Journal , 2 (1), $1-18$. Retrieved from https://ejournal2.undip.ac.id/index.php/dialogue/article/view/8182

Zavattaro, SM, \& McCandless, SA (2020). Editor's introduction: Our public service manifesto during pandemic. Administrative Theory and Praxis, 42 (2), 233239. https://doi.org/10.1080/10841806.2020.1752593 
318 Jurnal Ilmiah Ilmu Administrasi Publik: Jurnal Pemikiran dan Penelitian Administrasi Publik

Volume 10 Number 2, July-December 2020. Page 307-318 